\title{
PEMBENTUKAN KARAKTER SANTRI MILENIAL MELALUI MODEL PENGASUHAN BERBASIS TONTONAN EDUKASI ISLAMI DI MADRASAH IBTIDAIYAH NURUL MUN'IM PONDOK PESANTREN NURUL JADID PROBOLINGGO
}

\author{
Faizatul Widat ${ }^{1}$, Fitria Nur Hayati ${ }^{2}$, Muniva Muslimah ${ }^{3}$ \\ Universitas Nurul Jadid \\ faizatulwidat59@gmail.com,fitrianurhayati030900@gmail.com
}

\begin{abstract}
This study aims to describe the character formation of millennial students through a parenting model based on Islamic education spectacles for students at Madrasah Ibtidaiyah Nurul Mun'im Karanganyar Paiton Probolinggo. This research uses a qualitative approach with the type of case study. Analysis of research data using the Miles and Hubarman technique. The results of the study show that the Islamic educative parenting model manifests changes in the character of students who are getting better, such as: increased acts of mutual help, honesty in words and actions, and positive responses to the social environment. The implication of character building through Islamic education shows is one solution for parents and educators who are trying to shape, develop or improve children's character.
\end{abstract}

Keywords: Character Building, Millennial Santri, Parenting Model, Islamic Education

\begin{abstract}
Abstrak: Penelitian ini bertujuan untuk mendeskripsikan pembentukan karakter santri milenial melalui model pengasuhan berbasis tontonan edukasi islami pada pelajar di Madrasah Ibtidaiyah Nurul Mun'im Karanganyar Paiton Probolinggo. Penelitian ini menggunakan pendekatan kualitatif dengan jenis studi kasus. Analisis data penelitian dengan teknik Miles dan Hubarman. Hasil penelitian menunjukkan, model pengasuhan tontonan edukatif islami mewujudkan adanya perubahan karakter santri yang semakin membaik, seperti: meningkatnya perbuatan saling tolong menolong, kejujuran perkataan dan perbuatan, serta adanya respon positif terhadap lingkungan sosial. Implikasi pembentukan karakter melalui tontonan edukasi islami menjadi salah satu solusi bagi orangtua dan pendidik yang tengah berupaya dalam membentuk, mengembangkan atau memperbaiki karakter anak.
\end{abstract}

Kata Kunci: Pembentukan Karakter, Santri Milenial, Model Asuhan, Edukasi Islami

FONDATIA : Jurnal Pendidikan Dasar Volume 5, Nomor 2, September 2021; 180-196 https://ejournal.stitpn.ac.id/index.php/fondatia 


\section{PENDAHULUAN}

Anak merupakan investasi terbesar bagi orangtua, kebaikan perilaku anak pun menjadi dambaan bagi setiap orangtua. Kebaikan perilaku anak dapat terwujud bila anak memiliki akhlak, kepribadian serta tingkah laku yang baik. Ulasan mengenai 3 hal tersebut tidak pernah terlepas dari pembahasan karakter. Mengenai pembinaan karakter baik dalam diri anak muda sebagai penerus bangsa sangat dibutuhkan pada zaman modern dan serba digital seperti saat ini, sebab sekali mereka terkepung dalam akhlak atau karakter yang tidak baik, maka tak dapat ditepis lagi gerbang kehancuran yang menanti di depan mata ${ }^{1}$.

Pendeskripsian karakter dalam KBBI dideskripsikan sebagai sifat-sifat kejiwaan, akhlak atau budi pekerti, tabiat ataupun watak yang dapat membuat seseorang nampak berbeda dari yang lain. Menurut Nurmalasari dan Jayanti, berpendapat bahwa perwatakan seseorang dapat bersumber dari faktor genetik dan non-genetik.

Watak yang bersumber dari faktor genetik ialah watak pembawaan yang ada dalam diri anak sejak ia dilahirkan. Sedangkan watak yang bersumber dari faktor nongenetik merupakan tabiat diri yang pembentukannya dipengaruhi oleh pendidikan, pengalaman dan lingkungan ${ }^{2}$. Kemudian Yuliharti menguatkan bahwa inti karakter islami ialah akhlaq al-karimah terhadap Allah Swt. dan sesama makhluk. Akhlak alkarimah yang dimaksud yaitu perilaku, sifat, tabiat, akhlak yang dilandasi oleh nilainilai islam yang bersumber dari al-Quran dan Hadis Nabi Muhammad Saw. ${ }^{3}$.

Berdasarkan watak yang bersumber dari faktor non-genetik tersebut, maka karakter perlu dibentuk melalui proses panjang yang bertahap. Untuk membentuk karakter anak yang baik dan sesuai harapan, pendidik (orangtua dan guru) dapat

\footnotetext{
${ }^{1}$ Fathor Rozi and Innani Kholidatul Jannah, 'Revitalisasi Pemberdayaan Budaya Karakter Nuansa Religiustik Dalam Membentuk Perilaku Pekerti Santri', Jurnal Murobbi: Jurnal Ilmu Pendidikan, 5.1 (2021), 17-34 <https://doi.org/10.52431/murobbi.v5i1.334>.

${ }^{2}$ Eka Jayanti and Wanty Eka Jayanti, Buku Character Building Ini Adalah Buku Ajar Yang Disusun Oleh Penulis Sebagai Upaya Memberikan Kesadaran Kepada Generasi Muda Dalam Meningkatkan Dan Mengembangkan Karakter Positif Diri. Buku Ini Mengulas Betapa Pentingnya Pembentukan Karakter Untuk. Menj, 2013.

3 Yuliharti Yuliharti, 'Pembentukan Karakter Islami Dalam Hadis Dan Implikasinya Pada Jalur Pendidikan Non Formal', POTENSLA: Jurnal Kependidikan Islam, 4.2 (2019), 216 <https://doi.org/10.24014/potensia.v4i2.5918>.
} 
melakukan berbagai macam cara, salah satunya ialah melalui pemberian asuhan berupa tontonan edukasi islami. Film animasi edukasi islami tidak hanya memberikan pengaruh terhadap proses terbentuknya karakter, namun film tersebut juga dapat memberikan pengajaran yang melekat dalam diri anak terkait ajaran-ajaran islam maupun akhlakul karimah yang terkandung dalam sajian film/kartun yang pada umumnya berdurasi antara 5-25 menit ${ }^{4}$.

Pembentukan karakter pada diri anak jelas sekali urgensinya, sehingga Fatmah menyebutnya sebagai bagian integral dalam dunia pendidikan islam ${ }^{5}$. Pembentukan karakter dalam diri anak tidak hanya dapat dilaksanakan di lingkungan sekolah saja, lingkungan keluarga dan masyarakat juga dapat menjadi tempat untuk pembentukan karakter. Hasil penelitian mengenai pendidikan dan pembentukan karakter oleh Sinaga membuktikan bahwa anak usia SD/MI cenderung akan menirukan sesuatu yang didengar dan dilihatnya. Oleh karena itu, karakter yang berkualitas perlu dibentuk dan dibina sejak anak usia dini karena masa ini merupakan masa kritis bagi pembentukan karakter seseorang ${ }^{6}$.

Fardani dan Lismanda mengutip pendapat Maria Montessori yang mengemukakan bahwa secara umum, anak pada usia dini / belia memiliki The Absorbent Mind, yakni ingatan yang dapat mengisap segala sesuatu yang dirasakan, didengarkan dan dilihat ${ }^{7}$. Dari ingatan inilah, anak akan memunculkan sikap-sikap yang telah diresapinya yang tidak jauh berbeda dengan apa yang diingatnya. Maka dari itu, Sudrajat dan Wibowo mengemukakan bahwa para guru harus menjadi dan memberikan contoh yang dapat menjadi teladan baik bagi peserta didiknya ${ }^{8}$. Teladan yang dicontohkan harus ditekankan pada pembentukan nilai-nilai tertentu (jujur,

\footnotetext{
${ }^{4}$ Airani Demillah, 'Peran Film Animasi Nussa Dan Rara Dalam Meningkatkan Pemahaman Tentang Ajaran Islam Pada Pelajar SD', Jurnal Interaksi: Jurnal Ilmu Komunikasi, 3.2 (2019), 106-115 <https://doi.org/10.30596/interaksi.v3i2.3349>.

5 'Volume 29 Nomor 2 Juli-Desember 2018 369', 29 (2018), 369-387.

${ }^{6}$ Rida Sinaga, 'Pendidikan Karakter Pada Anak Usia Dini', Societas Dei: Jurnal Agama Dan Masyarakat, 5.2 (2018), $180<$ https://doi.org/10.33550/sd.v5i2.89>.

${ }^{7}$ Diah Novita Fardani and Yorita Febry Lismanda, 'Nilai-Nilai Pendidikan Karakter Untuk Anak Usia Dini Dalam Film "Nussa”, Thufuli: Jurnal Ilmiah Pendidikan Islam Anak Usia Dini, 1.2 (2019), 34 <https://doi.org/10.33474/thufuli.v1i2.4921>.

8 Ajat Sudrajat, 'Pembentukan Karakter Terpuji Di Sekolah Dasar Muhammadiyah Condongcatur', Jurnal Pendidikan Karakter, III.2 (2013), 174-185 <https://doi.org/10.21831/jpk.v2i2.1438>.
} 
sopan santun, tanggungjawab, adil, peduli) dan pemahaman siswa untuk melakukan nilai-nilai tersebut dalam kehidupan ${ }^{9}$.

Di era digital saat ini, hampir setiap insan memiliki gawai/HP android, sehingga dengan segala kemudahan akses internet bisa menikmati berbagai jenis tontonan yang disuguhkan oleh situs web youtube. Tontonan yang ditawarkan memiliki konten yang beragam, mulai dari edukasi, lifestyle, musik, entertainment, komedi, film/kartun dan animasi, travelling, gaming, berita, pets dan animals, science dan technology, olahraga, daily activities, hingga konten bidang otomotif. Aplikasi youtube menjadi salah satu media hiburan di kala senggang. Segala tontonan yang ada pada aplikasi youtube merupakan tontonan bebas yang dapat diakses oleh siapa pun.

Dan pada umumnya, anak-anak usia SD/MI mengabaikan kelayakan konten video youtube yang ditontonnya, sehingga tanpa arahan dari orang yang lebih dewasa, anak akan menonton video-video tersebut sesuka hatinya. Padahal, tidak menutup kemungkinan, ada berbagai unsur kekerasan dan tidak bermoral pada video-video yang mereka tonton, sehingga kebiasaan tersebut akan sangat berdampak pada pembentukan karakter dalam diri anak.

Untuk menyiasati hal tersebut, terdapat aplikasi yang dapat membantu orangtua ataupun guru dalam memantau aktivitas gawai si anak, yakni aplikasi youtube kids. Hal ini berbeda dengan aplikasi youtube pada umumnya, jika aplikasi ini ada pada gawai anak-anak, maka ketika anak berselancar di youtube kids, secara otomatis akan memfilter tontonan-tontonan yang cocok untuk usia anak-anak saja. Maka pengasuhan yang berbasis tontonan edukasi seperti inilah yang perlu digencarkan agar anak terbiasa dengan beragam tontonan yang mengedukasi dirinya.

Lembaga Sensor Film Indonesia pun juga telah memiliki acuan kategori tontonan berdasarkan jenjang usia. Adanya keterangan usia berfungsi untuk menginformasikan kepada para penonton level-level usia yang diperbolehkan menonton tayangan tersebut. Kategori usia tersebut ialah sebagai berikut ${ }^{10}:$ 1) A/SU = Anak/Semua umur; 2) A-BO = Anak-Bimbingan Orangtua (usia 4-7 tahun); 3)

\footnotetext{
9 Ajat Sudrajat, 'Mengapa Pendidikan Karakter', Jurnal Pendidikan Karakter, I.1 (2011), 47-58 $<$ https://doi.org/10.21831/jpk.v1i1.1316>.

${ }^{10}$ Amin Arif Al Khakim and Dyah Ayu Aprilia Wahyu Sofiana, 'Pemilihan Film Anak Dan Kaitannya', 2019, 150-60.
} 
$\mathrm{BO}=$ Bimbingan Orangtua (usia 5-12 tahun); 4) R-BO = Remaja-Bimbingan Orangtua (usia 13-16 tahun); 5) $\mathrm{D}=$ Dewasa (usia $>17$ tahun).

Permasalahannya ialah, apakah anak-anak yang masih berusia antara 4-12 tahun akan memperhatikan kategori usia tersebut jika dibiarkan dan dilepas menonton sendirian. Melihat hal tersebut, di sinilah letak pentingnya pengawasan seseorang yang lebih dewasa, baik pendidik yang ada di lingkungan sekolah, maupun orangtua yang ada dalam lingkup keluarga.

Keluarga inti merupakan lembaga terkecil yang bertanggungjawab mendidik anak dengan tujuan menjadikannya insan yang bermoral ${ }^{11}$. Seperti pepatah masyhur yang banyak menghiasi telinga kita bahwa jatuhnya buah tidak akan jauh dari batang pohonnya. Dalam pembentukan karakter, pepatah tersebut menghadirkan sebuah makna krusial bahwa karakter yang terbentuk dalam diri anak merupakan pengakumulasian dari diri pribadi, lingkungan keluarga, sekolah dan masyarakat.

Dalam menonton tayangan edukatif, pihak pendamping berkewajiban mendampingi anak-anak untuk mempertanyakan nilai pesan moral dan karakter yang dapat diteladani dari film atau kartun yang telah ditontonnya. Pendampingan ini bertujuan untuk menyelamatkan anak dari kesalahan dalam memetik pesan moral dan karakter pada film/kartun.

Pendamping juga perlu memberikan pemahaman mengenai betapa pentingnya melaksanakan nilai-nilai moral dan meneladani karakter-karakter tersebut. Sebagai suatu contoh, anak mendapatkan sebuah pelajaran penting dalam kartun bahwa berkata bohong bisa membuat diri mendapatkan sanksi atau hukuman. Dari hal ini, pendamping perlu meluruskan pemahaman anak serta memberikan penguatan bahwa kebohongan dapat membawa kegundahan yang tiada akhirnya dan kejujuran dapat menghantarkan hati pada keadaan damai serta ketenangan jiwa dan raga.

Penelitian terdahulu terkait pembentukan karakter telah dilakukan oleh banyak peneliti di antaranya Muhammad Sobri dan Nursaptini ${ }^{12}$. Dalam hasil

${ }^{11}$ Hidar Amaruddin, Hamdan Tri Atmaja, and Muhammad Khafid, 'Peran Keluarga Dan Media Sosial Dalam Pembentukan Karakter Santun Siswa Di Sekolah Dasar', Jurnal Pendidikan Karakter, 10.1 (2020), 33-48 < https://doi.org/10.21831/jpk.v10i1.30588>.

12 Muhammad Sobri and others, 'Pembentukan Karakter Disiplin Siswa Melalui Kultur Sekolah', Harmoni Sosial: Jurnal Pendidikan IPS, 6.1 (2019), 61-71 < https://doi.org/10.21831/hsjpi.v6i1.26912>. 
penelitian tersebut dijelaskan bahwa proses pembentukan karakter disiplin siswa terbentuk melalui beberapa unsur identifikasi kultur sekolah antara lain: artifak sekolah, tata tertib sekolah, ritus atau upacara-upacara, serta nilai-nilai atau keyakinan yang dianut setiap warga sekolah. Berikutnya ialah Aat Hidayat ${ }^{13}$ yang memaparkan bahwa penerapan pembentukan karakter terhadap generasi islam milenial dapat dipraktikkan dalam setiap proses pembelajaran dengan cara mendesain serta mengintegrasikan proses belajar dengan nilai-nilai pendidikan berkarakter yang meliputi nilai religi, kejujuran, toleransi, sikap disiplin, mampu bekerja keras, mandiri, memiliki kreativitas, berjiwa demokratis, memiliki rasa ingin tahu, semangat kebangsaan, cinta tanah air, menghargai prestasi, komunikatif, cinta perdamaian, gemar berliterasi, peduli lingkungan, peduli sosial, dan memiliki tanggungjawab. Penelitian terbaru oleh Chusnul Muali dkk ${ }^{14}$ yang memaparkan berbagai tantangan sebagai seorang santri di era milenial yakni perbedaan budaya dan kepribadian santri utamanya dalam cara berkomunikasi, sehingga seorang santri perlu beradaptasi dengan perbedaan tersebut. Tantangan lainnya ialah kebutuhan seorang santri terhadap panutan baik yang dapat dijadikan teladan serta kemajuan IPTEK yang menjadi tantangan bagi para santri agar tidak tertinggal dengan kemajuan dan perkembangan zaman. Usaha preventif untuk meminimalisir terjadinya tantangantantangan tersebut di atas ialah dengan membina karakter para santri melalui pembinaan perilaku berkarakter islami.

Penelitian ini dilatarbelakangi oleh berbagai fenomena yang terjadi di masyarakat di antaranya: Menjamurnya generasi muda yang memiliki karakter kurang baik dalam hal budi pekerti; Tontonan edukatif yang dinilai dapat membentuk karakter anak; serta Minimnya kemampuan dan pengetahuan orangtua mengenai cara membentuk karakter anak supaya memiliki kepribadian yang baik dalam hal budi pekerti. Ketidakmampuan orangtua dalam memanfaatkan media tontonan film/kartun sebagai perantara pembentukan karakter ini membutuhkan dukungan dari berbagai pihak untuk turut andil dalam memberikan edukasi kepada anak.

\footnotetext{
${ }^{13}$ Fakultas Tarbiyah and Iain Kudus, '1 , 2 , 3', 59-81.

${ }^{14}$ Chusnul Muali and others, 'Tantangan Pendidikan Pesantren Dalam Membina Karakter Santri Milenial', Jurnal Pendidikan Islam, 3.2 (2020), 131-46 < http://jurnal.staiannawawi.com/index.php/AtTarbiyat/article/view/225>.
} 
Dari perihal tersebut, maka penelitian ini memberikan suatu penawaran unik dalam hal memanfaatkan media tontonan film/kartun edukatif sebagai suatu cara dalam pembentukan karakter anak sejak usia sekolah dasar. Hal yang membedakan penelitian ini dengan penelitian lainnya ialah pemberian asuhan tontonan bersifat edukatif islami yang diberikan kepada para santri MINM kelas V dan VI yang ratarata masih mondok di pondok pesantren Nurul Jadid yang kesehariannya (sejak pagi hingga siang hari) mengikuti pembelajaran umum di sekolah. Subjek penelitian tersebutlah yang menjadi hal baru dalam penelitian ini, yakni pengasuhan berbasis tontonan edukasi islami yang diberikan kepada para santri yang mondok untuk menuntut ilmu agama sekaligus ilmu umum.

Penelitian ini menjadi penting untuk dilakukan karena: Pertama, ketika para santri berkumpul dengan teman sekelasnya yang kebetulan tidak mondok, pada jam istirahat mereka seringkali berselancar di aplikasi youtube dan lainnya yang kebanyakan mengandung konten-konten yang tidak layak dijadikan tontonan anakanak yang masih berusia 6-12 tahun. Kedua, memperkenalkan para santri yang masih duduk di kelas V dan VI kepada kemajuan IPTEK sehingga mereka dapat mengetahui dan tidak menyalahgunakan kemajuan IPTEK tersebut dalam hal-hal yang berbau negatif dan tidak baik.

Melihat karakter santri milenial di pondok pesantren, tim peneliti memfokuskan penelitian pada pembentukan karakter santri di pondok pesantren tepatnya santri MI Nurul Mun'im Paiton-Probolinggo kelas V dan VI. Fokus penelitian tersebut berdasarkan pada pengamatan peneliti yang menemukan berbagai permasalahan mengenai karakter santri milenial di MINM.

Permasalahan utama pada karakter santri MINM yaitu masih banyak santri yang bersikap tidak jujur dalam perkataannya, cara berkomunikasi yang masih banyak menggunakan bahasa kurang santun, dan ada beberapa santri yang kurang peduli terhadap kebersihan lingkungan sekolah. Selain hal tersebut, masih ditemukan beberapa santri yang kurang disiplin dalam mengatur waktu sehingga berakibat pada seringnya terlambat datang ke sekolah. Tim peneliti juga menemukan adanya bullying terhadap sesama teman yang dapat mengakibatkan kurangnya tenggang rasa. 
Dari berbagai permasalahan yang ditemukan tersebut, tim peneliti berasumsi bahwa pemberian stimulus berupa media tontonan edukasi islami dapat memperbaiki perilaku yang kurang baik tersebut. Tim peneliti memberikan stimulus berupa tontonan edukasi yang berjudul 'Kisah Sahabat Nabi-Kemuliaan Abu Bakar AshShiddiq'. Dengan demikian, dari berbagai fakta dan isu yang terjadi, maka penelitian ini bertujuan untuk mengetahui keberhasilan pembentukan karakter santri yang islami melalui tontonan film anak/kartun yang memberikan pesan edukatif serta kesan positif yang dapat diteladani oleh anak-anak.

\section{METODE PENELITIAN}

Penelitian ini dilaksanakan di Madrasah Ibtidaiyah Nurul Mun'im yang berada di Desa Karanganyar, Kecamatan Paiton, Kabupaten Probolinggo dengan subyek penelitian santri/siswa kelas V dan VI. Penelitian yang dilaksanakan merupakan penelitian lapangan jenis kualitatif. Metode penelitian kualitatif ialah metode penelitian berlandaskan filsafat postpositivisme ${ }^{15}$ yang mengacu pada realitas/gejala/fenomena yang terjadi secara alamiah pada objek ataupun subjek penelitian. Pemilihan metode ini bermaksud untuk memahami fenomena yang dialami oleh subjek penelitian, baik perilaku, persepsi, motivasi, tindakan, dan lainnya. Jenis penelitian menggunakan studi kasus dimana peneliti akan meneliti secara mendalam untuk mengetahui keberhasilan pembentukan karakter dalam diri santri melalui tontonan bersifat edukasi islami.

Data penelitian diperoleh melalui teknik pengumpulan data yakni observasi lapangan, wawancara dan dokumentasi. Perolehan data lapangan dianalisis menggunakan teknik analisis data Miles dan Hubarman yang mencakup tiga tahapan berikut: pengorganisasian data, penyajian data, dan penarikan kesimpulan. Setiap data yang diperoleh akan dimaknai dan ditarik kesimpulan Pemeriksaan keabsahan data dilakukan dengan mengadakan triangulasi dengan sumber-sumber yang relevan.

Subjek penelitian adalah santri Madrasah Ibtidaiyah Nurul Mun'im yang duduk di bangku kelas V dan VI. Sebelum melaksanakan penelitian, tim peneliti

${ }^{15}$ Uhar Suharsaputra, Metode Penelitian Kuantitatif, Kualitatif, Dan Tindakan, 2012. 
mengadakan observasi dan wawancara kepada lembaga sekolah dan beberapa tenaga pendidik mengenai upaya yang dilakukan dalam membentuk karakter para santri. Secara keseluruhan, rata-rata pendidik belum menerapkan proses pembelajaran yang diintegrasikan dengan nilai-nilai karakter yang ada dalam kartun atau film animasi islami.

\section{HASIL DAN PEMBAHASAN}

\section{Karakter Santri Milenial Madrasah Ibtidaiyah Nurul Mun'im}

Karakter sangat erat kaitannya dengan suatu sifat yang secara alamiah ada dan melekat dalam hati dan jiwa seseorang, sifat-sifat yang bertalian dengan akhlak dan budi pekerti tersebut dapat membedakan seseorang dengan orang lain. Dalam sebuah buku ${ }^{16}$, definisi karakter menurut Imam Al-Ghazali ialah karakter lebih dekat dengan akhlak, layaknya kedekatan antara indra penglihatan dan pendengaran manusia. Dalam buku tersebut dijelaskan, Imam Al-Ghazali berpendapat bahwa karakter merupakan sikap dan perbuatan yang telah menyatu dalam diri manusia sehingga muncul secara spontan ketika berinteraksi dengan lingkungan. Karakter yang merupakan sikap yang melekat pada diri manusia perlu dibentuk sejak dini, salah satunya melalui proses pendidikan. Pendidikan terkait karakter harus dilaksanakan secara berkesinambungan, sejak TK, SD, SMP, SMA, SMK bahkan hingga perguruan tinggi ${ }^{17}$, sehingga hasil yang nampak pada perilaku pribadi akan semakin membaik dari waktu ke waktu.

Pembentukan karakter santri dapat diimplementasikan dalam setiap proses pengajaran dan pendidikan, baik di lingkungan pondok pesantren, lingkungan madrasah, ataupun lingkungan keluarga dan masyarakat. Konsep pembentukan karakter santri milenial di MINM yang dilakukan oleh tim peneliti menggunakan

${ }^{16}$ R.A. Sani and M. Kadri, Pendidikan Karakter: Mengembangkan Karakter Anak Yang Islami (Jakarta: Bumi Aksara,

<https://books.google.com/books/about/Pendidikan_Karakter.html?hl=id\&id=Vq_xDwAAQBAJ $>$.

${ }^{17}$ Aji Bagus Priyambodo, 'Implementasi Pendidikan Karakter: Semagat Kebangsaan Dan Cinta Tanah Air Pada Sekolah Berlatang Islam Di Kota Pasuruan', Jurnal Sains Psikologi, 6.1 (2017), 9-15 $<$ https://media.neliti.com/media/publications/128733-ID-implementasi-pendidikan-karaktersemanga.pdf $>$. 
metode model pengasuhan berbasis tontonan edukasi islami. Model pengasuhan ini ditujukan kepada santri MINM kelas V dan VI.

Pembentukan karakter merupakan upaya yang dilakukan oleh tim peneliti dalam membentuk karakter santri yang sebelumnya kurang baik menjadi karakter yang lebih baik. Pembentukan karakter sangat penting untuk membentuk akhlak baik seorang santri, antara lain: terbentuknya sikap jujur, disiplin, amanah, adil, toleransi, kerja keras, dan karakter-karakter baik lainnya.

Terlepas dari hal-hal tersebut di atas, terdapat beragam karakter yang dapat diajarkan dan dibentuk melalui berbagai macam cara, metode ataupun model. Tujuan utama pembentukan karakter adalah untuk mengajarkan dan membentuk nilai-nilai karakter agar hal tersebut dapat dijadikan landasan berperilaku dalam setiap tindakan ${ }^{18}$. Berangkat dari tujuan ini, Depdiknas telah mengembangkan 18 atribut karakter untuk memudahkan pengidentifikasian karakter yang baik, di antaranya ${ }^{19}$ : Religius; Jujur; Toleran; Disiplin; Bekerja keras; Kreatif; Mandiri; Bersikap demokratis; Kritis; Nasionalisme; Cinta tanah air; Menghargai prestasi; Komunikatif; Mencintai perdamaian; Gemar berliterasi; Peduli lingkungan; Peduli sosial; Bertanggungjawab.

Dari 18 karakter di atas, ada 3 karakter utama yang perlu dibentuk dalam diri santri MINM kelas V dan VI. 3 karakter tersebut antara lain: jujur, disiplin, dan peduli sosial serta lingkungan. Sikap jujur yang perlu dibentuk dalam diri santri MINM ialah sikap dan perilaku jujur dalam setiap perkataan dan perbuatannya. Sikap disiplin pada diri santri MINM kelas V dan VI juga perlu ditingkatkan, utamanya disiplin terhadap waktu dan taat peraturan madrasah. Rasa peduli sosial dalam diri santri juga perlu ditingkatkan untuk menumbuhkan sifat tenggang rasa sehingga santri MINM kelas V dan VI lebih mempunyai rasa hormat terhadap yang lebih tua dan rasa menyayangi terhadap yang lebih muda.

Santri MINM kelas V dan VI rata-rata memiliki karakter yang baik. Dalam observasi terhadap karakter santri milenial yang dilakukan tim peneliti, santri MINM kelas V dan VI memiliki kebiasaan yang baik dalam hal memulai dan mengakhiri

18 Octavian Muning Sayekti, 'Film Animasi "Nussa Dan Rara Episode Baik Itu Mudah" Sebagai Sarana Penanaman Karakter Pada Anak Usia Dini', Jurnal Pendidikan Anak, 8.2 (2019), 164-71 <https://doi.org/10.21831/jpa.v8i2.29093>.

${ }^{19}$ Kemendiknas, Pedoman Pendidikan Budaya Karakter Bangsa (Jakarta: Balitbang Pusat Kurikulum, 2010). 
setiap kegiatan pembelajaran yaitu seperti berjabat tangan kepada guru dan berdoa bersama sebelum memulai pembelajaran. Hasil observasi juga menunjukkan santri MINM juga memiliki sifat mandiri yang tercermin dalam kepribadian santri yang sudah mampu menetap di pondok pesantren sejak usia 6-7 tahun dan tidak tinggal bersama orangtua sehingga para santri terbiasa menjalani kehidupan sehari-hari dengan sendirinya. Sehingga dapat dikatakan bahwa karakter santri MINM kelas V dan VI yang dapat hidup mandiri telah mencerminkan karakter santri milenial yang taat akan peraturan pesantren dan madrasah.

Ketaatan para santri tersebut mampu menjadi penyaring pergaulan bebas dari luar lingkungan pesantren. Namun dalam perihal akhlak, masih ditemukan adanya akhlak yang kurang baik pada diri santri MINM kelas V dan VI seperti suka berbicara bohong dan peneliti juga mendapati beberapa santri masih suka mengolok-olok teman sebayanya. Maka dari itu, perlu diberikan asuhan dan pengajaran kepada santri MINM kelas $\mathrm{V}$ dan VI mengenai keharusan berbuat jujur dan pentingnya untuk selalu berkata jujur dalam setiap hal.

\section{Model Pengasuhan Berbasis Tontonan Edukasi Islami Untuk Santri MINM kelas V dan VI}

Model asuhan merupakan sebuah pola atau cara yang dilakukan dalam memberikan sebuah asuhan guna menghasilkan sesuatu yang diharapkan. Dalam penelitian ini, hal yang diharapkan ialah terbentuknya beragam karakter mulia yang sesuai dengan 18 atribut karakter, terutama terbentuknya karakter jujur yang dapat dipetik dari seorang tokoh atau teladan.

Berbagai penelitian membuktikan bahwa pembentukan karakter yang diimplementasikan di lingkungan sekolah dapat mengacu pada beberapa cara berikut ${ }^{20}$, yaitu: 1. Melalui pembelajaran, 2. Melalui keteladanan, 3. Melalui penguatan, 4. Melalui pembiasaan. Selain cara-cara yang dicetus oleh Sudrajat di atas, Hadisi pun menyatakan bahwa membentuk karakter anak di lingkungan sekolah juga dapat diterapkan melalui metode pembelajaran yang telah diintegrasikan dengan pengenalan

20 Sudrajat, 'Mengapa Pendidikan Karakter'. 
karakter, metode tersebut antara lain: 1. Metode keteladanan, 2. Metode pembiasaan, 3. Metode bercerita, 4. Metode karyawisata ${ }^{21}$.

Salah satu model asuhan yang dapat dijadikan sebagai media pendidikan karakter dalam rangka membentuk karakter anak adalah melalui metode pembiasaan menonton tontonan-tontonan yang bernilai positif dan memberikan kesan edukatif. Hal ini dituangkan oleh Sani dalam karyanya yakni: Pendidikan karakter yang pada hakikatnya memberikan pendidikan nilai, moral, watak, dan budi pekerti merupakan suatu proses pendidikan yang mencakup unsur fikiran, perasaan, dan tindakan. Oleh karena hal tersebut, Sani menyebutkan terdapat beragam model asuhan yang dapat diaplikasikan oleh pendidik dalam usaha turut andil membentuk karakter anak tercinta, ragam usaha tersebut antara lain ${ }^{22}$ :

Pertama, melaksanakan perilaku baik terlebih dahulu sebelum mengajak anak untuk melaksanakannya. Esensi dari hal ini adalah pentingnya menunjukkan keteladan yang baik dalam setiap hal, tutur kata dan tindak tanduk. Merupakan sebuah mimpi belaka apabila seorang pendidik mengajak anak didik untuk berperilaku baik, namun pribadi pendidik masih belum dalam kategori karakter yang baik.

Kedua, membiasakan anak untuk berfikir baik, berperasaan baik dan bertindak baik dalam setiap hal (kebaikan adab, etika dan akhlak dalam segala hal). Baik dalam hubungan manusia dengan penciptanya, dalam hubungan manusia dengan sesamanya, bahkan dalam hubungan manusia dengan makhluk hidup lain (khususnya binatang).

Ketiga, meluangkan waktu untuk dapat memberikan wejangan nasihat terhadap anak seperti yang telah dicontohkan oleh Luqman tatkala memberikan pelajaran kepada anaknya, yang termaktub dalam kitab suci Al-Quran yang artinya "Dan ingatlah ketika Luqman berkata kepada anaknya, di waktu ia memberi pelajaran kepadanya: 'Hai anakku, janganlah kamu mempersekutukan Allab, sesunggubnya

${ }^{21}$ La Hadisi, 'Pendidikan Karakter Pada Anak Usia Dini La Hadisi', Jurnal Al-Ta'did, 8.2 (2015), 50-69 $<$ http://repository.iiq.ac.id/handle/123456789/228>.

22 Sani and Kadri. 
mempersekutukan Allah adalah benar-benar kezaliman yang besar' (Q.S. Luqman/31 ayat 13)".

Keempat, menyampaikan hikmah dari sebuah kisah atau cerita. Usaha ini dapat diterapkan pada anak-anak usia sekolah dasar yang rata-rata memiliki kegemaran menonton kisah atau cerita melalui film animasi maupun membacanya di buku-buku tertentu.

Dari hasil observasi terhadap santri MINM kelas V dan VI, maka model pengasuhan yang dipilih tim peneliti merupakan bentuk pola asuh berbasis tontonan edukasi islami menggunakan media youtube sebagai perantara dalam menampilkan contoh-contoh karakter jujur dan rasa empati. Tokoh yang menjadi teladan dalam tontonan (kartun animasi) tersebut adalah Abu Bakar Ash-Shiddiq sehingga karakter tokoh dalam cerita dapat menjadi cerminan santri MINM kelas V dan VI dalam berperilaku dengan upaya diimplementasikannya karakter tersebut di dalam kehidupan sehari-hari, baik ketika santri berada di madrasah, pondok ataupun rumahnya.

Dikarenakan karakter merupakan cerminan dari kebiasaan, sehingga apabila anak dibiasakan dengan tontonan edukatif yang bernilai karakter mulia, maka secara tidak langsung akan terbentuk karakter mulia dalam diri anak seperti yang ada pada tokoh film/kartun. Dari hasil pembiasaan tersebut, Hutasuhut mengemukakan bahwa film/kartun animasi merupakan salah satu solusi pembelajaran, terutama film/kartun animasi yang memuat pembelajaran karakter yang unik dan menarik ${ }^{23}$.

Sebelum memberikan model pengasuhan menonton kartu animasi, tim peneliti melaksanakan berbagai tahap terlebih dahulu. Dalam penelitian ini, tim peneliti berupaya membentuk karakter jujur dan suka menolong pada diri santri MINM kelas V dan VI melalui model asuhan berbasis tontonan edukasi islami. Adapun konsep tahap-tahap pembentukan karakter tersebut terbagi menjadi enam tahap yang selanjutnya peneliti menyebut tahapan OSERASI (observasi, seleksi, edukasi, rekognisi, akseptasi, reaksi), berikut tahapannya:

23 Ade Ratna and Sari Hutasuhut, 'Analisis Pengaruh Film Nussa Dan Rara Terhadap Empati Anak Usia Dini Di Kota Padang’, Jurnall Pendidikan Tambusai, 4.2 (2020), 1237-46. 
1. Tahap Observasi

Pada tahap observasi, tim peneliti melakukan peninjauan terhadap santri yang akan diberikan asuhan. Selama kurang lebih 5 hari, tim peneliti memperhatikan dan mencermati tingkah laku santri sehari-hari ketika berada di lingkungan sekolah dan kelas. Hasil observasi menunjukkan adanya karakter dalam diri santri yang teridentifikasi dalam karakter tidak baik, di antaranya: suka berbohong, enggan menolong teman yang kesulitan, minimnya rasa peduli sosial dan lingkungan.

2. Tahap Seleksi

Setelah mengidentifikasi karakter-karakter tersebut di atas, tim peneliti melakukan penyeleksian terhadap kartun animasi edukasi yang berisi tentang teladan dalam berperilaku jujur, gemar menolong sesama dan peduli terhadap lingkungan. Tim peneliti memilih satu tontonan edukasi islami yang bersumber dari channel youtube Kastari Animation Official, video kartun tersebut berjudul 'Kisah Sahabat Nabi-Kemuliaan Abu Bakar Ash-Shiddiq', naskah kartun ditulis oleh Abdul Fatah,Ls. Video tersebut berdurasi sekitar 15 menit.

3. Tahap Edukasi

Tahap edukasi dilaksanakan selama 15 hari. Tahap ini merupakan tahap dimana tim peneliti mempertontonkan kartun animasi yang telah dipilih dan disepakati pada tahap sebelumnya. Sembari menonton kartun animasi, tim peneliti memberikan beberapa keterangan yang perlu dijelaskan seperti esensi berbuat jujur dan manfaatnya terhadap diri sendiri dan sesama, konsekuensi yang akan diperoleh dari perilaku bohong, serta perintah rasulullah untuk saling menolong dan menghargai sesamanya.

4. Tahap Rekognisi

Setelah menjalani tahap edukasi, para santri harus menyebutkan nilai/pesan/hikmah apa saja yang diperolehnya dari tontonan dan pengajaran melalui video kartun kisah sahabat nabi. Pada tahap ini, para santri akan berusaha mengingat kembali (recall of memory) segala yang telah 
dilihat dan atau didengarnya kemudian para santri menjawab pertanyaanpertanyaan yang diajukan oleh tim peneliti.

5. Tahap Akseptasi

Tahap ini merupakan tahap pembenaran oleh para santri mengenai pelaksanaan edukasi dan rekognisi. Melalui tahapan ini, santri dapat menerima makna karakter baik yang harus ada dan dimiliki dalam jiwa santri. Para santri juga diajak untuk bisa merubah kebiasaan/sifat-sifat yang tidak baik sebelumya menjadi sifat dan karakter yang berakhlak karimah.

6. Tahap Reaksi

Tahap reaksi merupakan tahap pembuktian yang merupakan akumulasi dari tahapan sebelumnya. Pada tahap ini, pemahaman santri mengenai karakter jujur, gemar membantu dan menolong sesama serta peduli terhadap sosial dan lingkungan bukanlah hanya menjadi sebuah pemahaman teori belaka. Akan tetapi, segala bentuk pemahaman tersebut harus ada dan tercermin dalam perilaku keseharian para santri. Dengan demikian, pemahaman santri terhadap etika bukan hanya sebatas kata, namun dibuktikan dalam perilaku, tindak-tanduk, perkataan dan perbuatan sehari-hari.

\section{KESIMPULAN}

Berdasarkan hasil dan pembahasan penelitian berjudul "Pembentukan Karakter Santri Milenial Melalui Model Pengasuhan Berbasis Tontonan Edukasi Islami di Madrasah Ibtidaiyah Nurul Mun'im Pondok Pesantren Nurul Jadid Probolinggo" yang telah dijabarkan dapat ditarik kesimpulan. Pertama, rata-rata pendidik di lembaga MINM belum menerapkan proses pembelajaran yang diintegrasikan dengan nilai-nilai karakter yang ada dalam kartun atau film animasi islami. Kedua, pengasuhan berbasis tontonan edukasi islami yang diberikan kepada santri MINM kelas V dan VI selama 15 hari mewujudkan adanya perubahan karakter santri yang semakin hari nampak membaik. Ketiga, pemanfaatan kartun atau film animasi berjudul "Kisah Sahabat Nabi, Kemuliaan Abu Bakar ash-Shiddiq" sebagai 
sebuah model pengasuhan untuk membentuk karakter baik mendapatkan respon positif dari seluruh santri kelas V dan VI, sehingga tingkat keberhasilan pengasuhan ini terlihat dalam perubahan perilaku santri sehari-hari yang semakin membaik.

Implikasi pembentukan karakter melalui tontonan edukasi islami menjadi salah satu solusi bagi para orangtua dan pendidik yang tengah berupaya dalam membentuk, mengembangkan atau memperbaiki karakter anak mengingat pada era ini telah marak beragam jenis video yang mengandung konten yang beragam pula.

Keterbatasan peneliti dalam melakukan penelitian sangat disadari, namun peneliti berusaha dengan maksimal untuk menyelesaikan penelitian ini. Oleh karenanya, dibutuhkan penelitian lebih lanjut mengenai pembentukan karakter berbasis tontonan edukasi agar dapat melengkapi dan menyempurnakan penelitian sebelumnya.

\section{DAFTAR PUSTAKA}

Al Quraan dan Terjemahnya. (1978). Proyek Pengadaan Kitab Suci Al-Qur'an Departemen Agama Republik Indonesia.

Amaruddin, Hidar, Hamdan Tri Atmaja, and Muhammad Khafid, 'Peran Keluarga Dan Media Sosial Dalam Pembentukan Karakter Santun Siswa Di Sekolah Dasar', Jurnal Pendidikan Karakter, $10.1 \quad$ (2020), 33-48 <https://doi.org/10.21831/jpk.v10i1.30588>

Demillah, Airani, 'Peran Film Animasi Nussa Dan Rara Dalam Meningkatkan Pemahaman Tentang Ajaran Islam Pada Pelajar SD', Jurnal Interaksi: Jurnal Ilmu Komunikasi, 3.2 (2019), 106-15 <https://doi.org/10.30596/interaksi.v3i2.3349>

Fardani, Diah Novita, and Yorita Febry Lismanda, 'Nilai-Nilai Pendidikan Karakter Untuk Anak Usia Dini Dalam Film "Nussa", Thufuli: Jurnal Ilmiah Pendidikan Islam Anak Usia Dini, $1.2 \quad$ (2019), 34 < https://doi.org/10.33474/thufuli.v1i2.4921>

La Hadisi, 'Pendidikan Karakter Pada Anak Usia Dini La Hadisi', Jurnal Al-Ta'did, 8.2 (2015), 50-69 <http://repository.iiq.ac.id/handle/123456789/228>

Jayanti, Eka, and Wanty Eka Jayanti, Buku Character Building Ini Adalab Buku Ajar Yang Disusun Oleh Penulis Sebagai Upaya Memberikan Kesadaran Kepada Generasi Muda Dalam Meningkatkan Dan Mengembangkan Karakter Positif Diri . Buku Ini Mengulas Betapa Pentingnya Pembentukan Karakter Untuk Menj, 2013

Kemendiknas, Pedoman Pendidikan Budaya Karakter Bangsa (Jakarta: Balitbang Pusat Kurikulum, 2010)

Khakim, Amin Arif Al, and Dyah Ayu Aprilia Wahyu Sofiana, 'Pemilihan Film Anak 
Dan Kaitannya', 2019, 150-60

Muali, Chusnul, Adi Wibowo, Zaini Gunawan, and Immatul Hamimah, 'Tantangan Pendidikan Pesantren Dalam Membina Karakter Santri Milenial', Jurnal Pendidikan Islam, $\quad 3.2 \quad$ (2020), 131-46 <http://jurnal.staiannawawi.com/index.php/At-Tarbiyat/article/view/225>

Priyambodo, Aji Bagus, 'Implementasi Pendidikan Karakter: Semagat Kebangsaan Dan Cinta Tanah Air Pada Sekolah Berlatang Islam Di Kota Pasuruan', Jurnal Sains Psikologi, $\quad 6.1 \quad$ (2017), 9-15 $<$ https://media.neliti.com/media/publications/128733-ID-implementasipendidikan-karakter-semanga.pdf $>$

Ratna, Ade, and Sari Hutasuhut, 'Analisis Pengaruh Film Nussa Dan Rara Terhadap Empati Anak Usia Dini Di Kota Padang', Jurnall Pendidikan Tambusai, 4.2 (2020), $1237-46$

Sani, R.A., and M. Kadri, Pendidikan Karakter: Mengembangkan Karakter Anak Yang Islami (Jakarta: Bumi Aksara, 2016) <https://books.google.com/books/about/Pendidikan_Karakter.html?hl=id\&i $\mathrm{d}=\mathrm{Vq} \_\mathrm{xDwAAQBAJ}>$

Sayekti, Octavian Muning, 'Film Animasi "Nussa Dan Rara Episode Baik Itu Mudah" Sebagai Sarana Penanaman Karakter Pada Anak Usia Dini', Jurnal $\begin{array}{llll}\text { Pendidikan Anak, } & 8.2 & \text { (2019), }\end{array}$ <https://doi.org/10.21831/jpa.v8i2.29093>

Sinaga, Rida, 'Pendidikan Karakter Pada Anak Usia Dini', Societas Dei: Jurnal Agama Dan Masyarakat, 5.2 (2018), 180 <https://doi.org/10.33550/sd.v5i2.89>

Sobri, Muhammad, Nursaptini Nursaptini, Arif Widodo, and Deni Sutisna, 'Pembentukan Karakter Disiplin Siswa Melalui Kultur Sekolah', Harmoni Sosial: Jurnal Pendidikan IPS, 6.1 (2019), <https://doi.org/10.21831/hsjpi.v6i1.26912>

Sudrajat, Ajat, 'Mengapa Pendidikan Karakter', Jurnal Pendidikan Karakter, I.1 (2011), 47-58 < https://doi.org/10.21831/jpk.v1i1.1316>

—, 'Pembentukan Karakter Terpuji Di Sekolah Dasar Muhammadiyah Condongcatur', Jurnal Pendidikan Karakter, III.2 (2013), 174-85 <https://doi.org/10.21831/jpk.v2i2.1438>

Suharsaputra, Uhar, Metode Penelitian Kuantitatif, Kualitatif, Dan Tindakan, 2012

Tarbiyah, Fakultas, and Iain Kudus, '1 , 2 , 3', 59-81

'Volume 29 Nomor 2 Juli-Desember 2018 369', 29 (2018), 369-87

Yuliharti, Yuliharti, 'Pembentukan Karakter Islami Dalam Hadis Dan Implikasinya Pada Jalur Pendidikan Non Formal', POTENSLA: Jurnal Kependidikan Islam, 4.2 (2019), $216<$ https://doi.org/10.24014/potensia.v4i2.5918> 